Скляренко І.Ю., Смирнова І. М., Герчиков О.О., Сидорчук О.Р.

\title{
РОЗРОБКА І ВПРОВАДЖЕННЯ АЛГОРИТМУ БЕЗПЕЧНОГО МАНЕВРУВАННЯ СУДЕН ВНУТРІШНЬОГО ПЛАВАННЯ
}

У статті розглянуто проблеми забезпечення безпечного маневрування суден, наведено фактори виливу на маневрування суднами внутрішнього плавання, дано визначення системі автоматичного управління судном, щчо є основою процесу переходу до безекіпажних суден. Розглянуто види сучасних адаптивних авторульових систем управління суднами, досліджено їх основні особливості, щзо стало підгрунтям для розроблення системи підтримки прийняття рімень суднами.

Досліджено, щуо для розробки логічних структурних алгоритмів прийняття рішення приділяється увага розробки методів коригування планової траєкторії при управлінні розходженням суден. При великій їх кількості завдання значно ускладняються, $i$ судноводій змушений вирішувати тільки оперативні задачі. Оиінку ситуащії зміну відносного руху описано трьома характеристиками. Представлені модель задачі прийняття рішення, схема системи самонавчання, математична модель динамічної бази знань на основі чого було побудовано алгоритм функиіонування системи безпечного маневрування, щчо дозволяє провести побудову вирімальної функиії паралельно як в автоматизованому режсим, так і на основі експертної думки.

Ключові слова: система управління, маневрування, система підтримки прийняття рімень, база даних, алгоритм.

Постановка проблеми. Безпечне розходження суден у морі є однією з класичних проблем судноводіння. Для іiї вирішення була прийнята Конвенція про Міжнародні правила запобігання зіткненню суден у морі, додатком до якої є Правила МППСС-72 [1]. Виконання Правил МППСС-72 є обов'язковим для цивільних суден, однак їх застосування не гарантує безпеки мореплавання так як правила не враховують навігаційних обмежень в районі плавання; регламентують розбіжність двох судів, але не застосовні в разі зустрічі декількох суден.

На даний час МППСС-72 це основний інструмент для забезпечення безпечного розходження суден. Саме правилами регламентується робота судноводіїв, зокрема принципи і основні правила поведінки в різних ситуаціях зустрічі суден, проте в правилах не прописано чітких вказівок для дій судноводіїв для безпечного розходження в реальних умовах зустрічі судів та для конкретних маневрів і не розглядають ситуації одночасного розходження декількох суден. Крім того, правила самі по собі є джерелом невизначеності в описі ситуації розходження, зважаючи на неоднозначність трактування деяких приписів. Дії судноводіїв в морі для кожного, безпосередньо, визначається його власним досвідом. Тому, саме людський фактор є ключовим при рішенні для безпечного розходження суден в морі. Разом з тим, МППЗС72 залишається основним нормативним документом, що регламентує процеси розходження суден i ïх формалізацію у вигляді, придатному для використання в системах підтримки прийняття рішень (СППР) судноводія та $є$ актуальною науковою і практичною задачею. Важливість правил обумовлює необхідність розробки алгоритму безпечного маневрування суден, придатних для використання в СППР судноводія. 
Мета роботи. Метою дослідження розробка алгоритму функціонування системи безпечного маневрування, що дозволяє провести побудову функцій як в автоматизованому режимі, так і на основі експертної думки.

Виклад основного матеріалу досліджень. Одним 3 сучасних напрямів розвитку морського судноплавства $\epsilon$ системи безекіпажних суден. Розробка систем безекіпажних суден ставить нові завдання в галузі забезпечення безпеки мореплавства i, зокрема, такої важливої її складової, як забезпечення безпечного розходження суден у морі.

Автоматизація процесів управління - єдиний шлях ослаблення впливу людського фактора i кінцевою стадією цього процесу $\epsilon$ перехід до безекіпажних суден. В літературі [1] - [4] велика увага приділяється різним питанням автоматизації процесів розбіжності.

Основні принципи побудови інтелектуальних систем управління викладені в роботі [2]. Питання формалізації МППСС-72 розглянуті в роботі [3]. Траєкторний підхід до вирішення завдання безпечного розходження суден, що враховує вимоги МППСС-72, запропонований в роботах [4-5].

Перехід до безекіпажних судам призводить до того, що замість судноводія управління судном здійснює автомат, який приймає рішення. Це кардинально змінює постановку задачі забезпечення безпечного розходження суден в море, а саме:

- рішення приймається в автоматичному режимі;

- виключається вплив людського фактора;

- можливе прийняття кооперативних рішень декількома автоматами.

Система автоматичного управління (САУ) суден, які рухаються по курсу вирішує такі завдання як стабільність та маневрування.

Обслуговування умов безперервної роботи авторульового протягом усього часу плавання судна залежить від надійності роботи його елементів, тому необхідно розібрати також елементи та коректуючі пристрої, які забезпечать надійність їі роботи.

Існуючі на сьогоднішній день САУ судном, який рухається по курсу, залежно від прийнятих конструкцій та схем, здійснює роботу за принципами складання. Під дією виразного сигналу рульова машина перекладає руль i, тим часом, судно повертається на заданий курс. САУ курсом судна має привичну для автоматичної системи загальну схему, проте курсу надано наступні відмінні особливості:

1. Так як велика інерція судна, як об'єкта управління, зміни його гідродинамічних параметрів внаслідок змін швидкості ходу та завантаження вибір системних систем та коректуючих пристроїв у цілому обмежено [6]. Для забезпечення необхідних параметрів якості роботи САУ у різних режимах експлуатації необхідно введення додаткових пристроїв корекції та/або здійснення змін параметрів регуляторів в процесі руху судна.

2. САУ курсом судна мають внутрішні жорсткі зворотні зв'язки, що формують контури слідування.

3. Системи управління курсом повинні здійснювати свою роботу при випадкових зовнішніх зворотних зв'язках, прикладних до різних змінених систем

4. Внаслідок жорстких умовних експлуатацій та залучення відповідальної ролі подібних систем, в процесі розробки та реалізації має бути забезпечено як можна більшу надмірність даного САУ курсом судна. Таким чином при розширенні слід вибирати елементи та коректуючі пристрої, які не ведуть до ускладнення системи та зниження її надійності.

Розглянемо сучасні адаптивні авторульові системи управління суднами. Адаптивні системи, в яких перелаштовуються лише параметри, називаються самоналаштовуючими. Якщо вже перелаштовується структура, в цьому випадку говорять про системи самоорганізації. Перші з вищевказаних зазвичай містять основну систему управління, а також пристрій для оцінки найкращих параметрів. Другий тип 
адаптивних рульових основ визначається на алгоритмах нейронних мереж та нечіткої логіки [6-8].

Самоналаштовуючі АAР можна розділити на системи з частковою налаштуванням параметрів або з повною адаптацією системи в процесі експлуатації. ААР з частковою автоматичним настроюванням параметрів, використовуючи різні непрямі критерії оцінки якості роботи системи, не завжди мають достатню математичну підгрунтя і не забезпечують повною оптимізації системи управління курсом судна в різних умовах плавання.

До ААР 3 повністю автоматичним налаштуванням параметрів системи можна віднести авторульові, що використовують еталонну (коректувальну) математичну модель об'єкта або всієї СУ в цілому для адаптації реальної системи. У таких ААР сигнали, що впливають на параметри управління, формуються на підставі аналізу якості управління судна за отриманими даними модельованих і спостережуваних змінних стану.

Адаптація в подібних схемах адаптивних САУ курсом судна здійснюється наступним чином. На вхід еталонної моделі і реального об'єкта надходить однаковий сигнал. 3 виходу еталонної моделі знімається кутова швидкість повороту, яка відповідає бажаній реакції судна. Відбувається порівняння кутової швидкості повороту 3 фактичної кутовою швидкістю судна різниця якої використовується для формування коригуючого сигналу. Блок адаптації забезпечує автоматичне налаштування параметрів управління на основі цього сигналу. Можуть бути різні способи використання еталонної моделі в системі, яка може відповідати повній замкнутій САУ або тільки об'єкту управління. До недоліків цього виду адаптації слід віднести необхідність виключення впливу зовнішніх впливів на стадії уточнення еталонної моделі.

Крім ААР, що використовують еталонну модель для настройки, існують так само системи, які самостійно налаштовуються, які досягають адаптивності шляхом використання математично обгрунтованого критерію якості, що дозволяє визначити оптимальні значення параметрів, що настроюються (рис. 1).

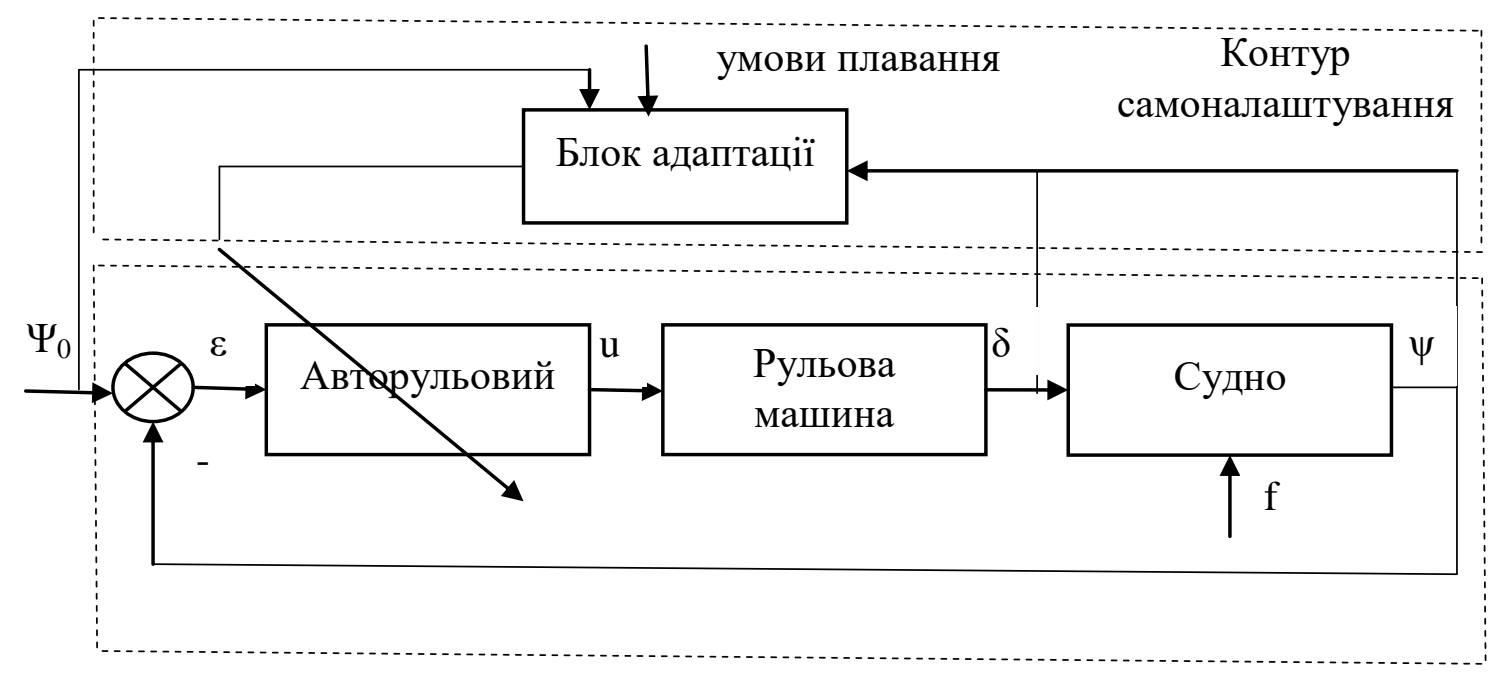

Основний контур управління

Рисунок 1 - Схема системи автоматичного управління з еталонною моделлю

Критеріями якості для таких ААР зазвичай виступають функціонали, що забезпечують мінімум втрат корисної потужності суднової силової установки при управлінні (тим самим мінімізується витрата палива) або дозволяють підібрати параметри регулятора найбільш точним чином (для забезпечення безпечного плавання, при знаходженні на близькій відстані декількох судів і т.д.). 
У ААР даного типу застосовується додатковий контур самонастроювання, призначений для виконання наступних функцій: отримання інформації про зовнішні дії і динамічні властивості основного контуру системи в процесі роботи; визначення за допомогою отриманої інформації чисельного значення критерію якості; формування відповідного керуючого сигналу для забезпечення оптимального режиму роботи САУ при мінімізації заданого критерію.

Для розробки логічних структурних алгоритмів прийняття рішення при приділяється увага розробки методів коригування планової траєкторії при управлінні розходженням суден. При великій їх кількості завдання значно ускладняються, і судноводій змушений вирішувати тільки оперативні задачі. Оцінку ситуації зміну відносного руху запропоновано описувати трьома характеристиками: розташуванням других суден відносно курсу власного - справа чи зліва; величини курсового кута між лінією відносного руху (ЛВР) і діаметральною площиною свого судна - $\alpha<90^{\circ}, \alpha=90^{\circ}, \alpha>90^{\circ}$; розташуванням ЛВР відносно власного судна (пересікає курс по носу, проходить через нас або пересікає лінію курсу по кормі). Зміну відносного руху будемо характеризувати двома параметрами: напрямком розвороту очікуваної лінії відносного переміщення (ОЛВР) відносно первісної ЛВР - по чи проти годинникової стрілки; зміною розташування ОЛВР по відношенню до власного - віддаляється від нас чи наближається. Метою всякого маневру для розходження полягає в тому, щоб ОЛВР віддалялась від нашого судна.

Для прийняття рішення розроблено модель задачі прийняття рішення, яка представляється у вигляді: <t, X, R, A, F, G, D>, де t - постановка задачі; X - множина допустимих альтернатив; $\mathrm{R}$ - множина критеріїв оцінки ступеню досягнення поставлених цілей; A - множина шкал вимірювання по критеріям (шкали найменувань, порядкові, інтервальні) F - відображення множини допустимих альтернатив у множину критеріальних оцінок; $\mathrm{G}$ - система переваг рішаючого елемента; D - рішаюче правило, що відображає систему переваг. Всі методи рішення багатокритеріальних задач можна звести до трьох груп [15]: - метод головного показника; - метод результуючого показника; - методи послідовних поступок.

Реалізуємо вибір варіанта рішення суднобригади за адитивним критерієм. 3 досвіду експлуатації суден члени сднобригади приймають під час керування судном основні елементарні рішення (для керування судном). Для система підтримки прийняття рішень (СППР) судна необхідно упорядкувати $\mathrm{m}$ варіантів рішення $\mathrm{a} 1, \mathrm{a} 2, \ldots$ am, що оцінюються за n критеріями $\mathrm{C} 1, \mathrm{C} 2, \ldots, \mathrm{Cn}$. Відповідна оцінка $-\mathrm{Rij}, \mathrm{i}=[1 ; \mathrm{m}], \mathrm{j}=[1 ; \mathrm{n}]$. Відносна важливість кожного критерія задана коефіцієнтом $\mathrm{Wj}$, причому $\sum_{j=1}^{n} W_{j}=1$. Тоді зважена оцінка і-го варіанта визначається як

$$
\mathrm{R}_{\mathrm{i}}=\sum_{j=1}^{n} W_{j} R_{j i}
$$

Нехай оцінки варіантів за критеріями і коефіцієнти відносної важливості задаються функціями приналежності відповідно $\mu_{R_{j i}}\left(r_{i j}\right)$ та $\mu_{W_{j}}\left(w_{j}\right)$.

$\mathrm{B}$ нашому випадку величини $\mathrm{Wj}$ та Rij є нечіткими числами. Розширені бінарні арифметичні операції над нечіткими числами визначаються через відповідні операції над чіткими числами з використанням принципу узагальнення.

Для вирішення поставлених задач вихідними даними для СППР виступають наступні дані:

- параметри судна;

- місце знаходження (координати;

- режим роботи судна;

- шлях усунення насправності;

- ймовірність транспортної пригоди; 
- момент та глибина;

- раціональне положення контролера;

- складність надзвичайної ситуації, яка включає зовнішні фактори, технічні фактори, людський фактор.

СППР судна буде представляти собою набір пристроїв, що забезпечать виконання наступних функцій:

- збір оперативної інформації про стан навколишнього середовища, в тому числі про режим руху;

- зберігання бази даних про суднобригади;

- зберігання та використання бази знань системи;

- доведення до члена екіпажу результатів роботи системи.

Аналізуючи умови роботи суднобригад, можна виділити наступні функції людини, які безпосередньо впливають на ефективність використання судна та безпеку i потребують підтримки за допомогою інтелектуальної системи [9]:

1) розпізнавання нештатної ситуації;

2) переведення штурвалу контролера члена суднобригади;

3) визначення моменту та глибини;

4) визначення способу усунення несправностей судна.

У системі, що розробляється, необхідною частиною є блок, відповідальний за оцінку станів об'єкта керування. Функціонування блоку оцінки стану грунтується на моделюванні дій людини, що приймає рішення, для чого використовується отримана від неї інформація. Тому зазначений блок включається в модель керування, що імітує поводження людини при керуванні об'єктом. Припустимо, що інформація, що подається на вхід блоку оцінки стау, може бути трьох типів: нечітка, чітка й нечітко множинна. Тип інформації визначається типом датчиків системи керування. Умовно виділимо три основних типи датчиків :

«нечіткі датчики» (людина-оператор, що подає на вхід блоку оцінки стану словесну інформацію про стан об'єкта керування);

«чіткі датчики» (деякі датчики, що подають на вхід блоку оцінки стану конкретну числову інформацію);

«аналогові датчики» (датчики, що подають на вхід блоку оцінки стану безперервні функції приналежності нечітких множин, які аналого-цифровим перетворювачем перетворяться у вектори ступенів приналежності).

Під самонавчанням будемо розуміти комплекс методів $\mathrm{i}$ алгоритмів для настроювання i функціонування інтелектуальних систем керування судном. Для використання пропонується структура системи, наведена на рис. 2.

Система, аналізуючи дані про стан параметрів, що впливають на рух судна, генерує керуючі сигнали, найбільш доцільні в поточній ситуації . Ці сигнали через інтерфейсну частину подаються в базу знань для подальшої перевірки їх на адекватність і ефективність.

Нечіткий класифікатор (НК) є основним елементом системи самонавчання. Від його роботи залежить ефективність навчання системи та в решті безпека руху судна.

НК представляє собою нечітку базу знань, на вхід якої подаються сигнали про поточний стан судна та навколишнього середовища. Для навчання (створення та уточнення правил нечіткої бази знань) використовується зовнішня база знань, яка відображає спектр керуючих сигналів в залежності від поточної поїзної обстановки. Вона утворена в результаті реальних поїздок і показує, яким чином виконувалось керування судном бригади. 


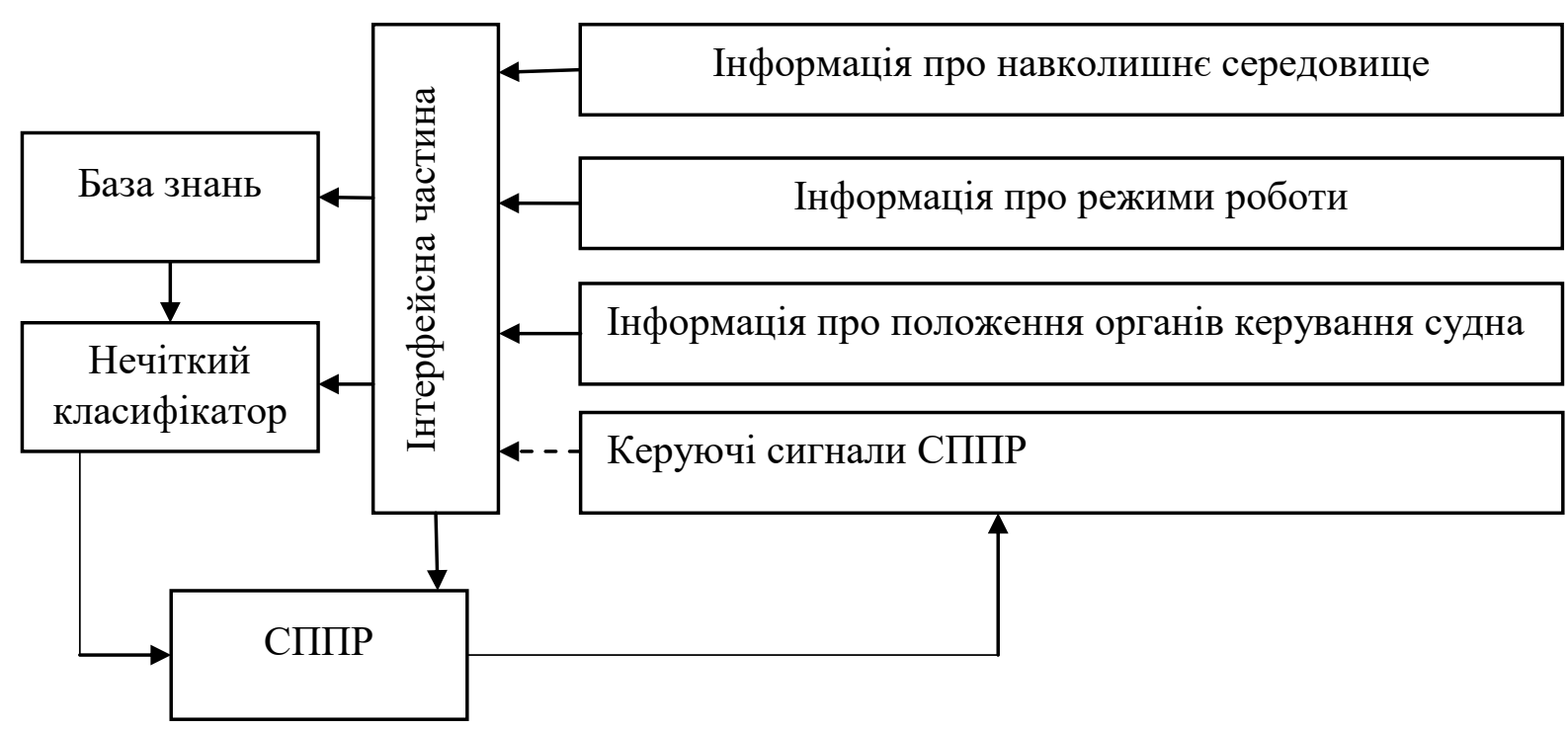

Рисунок 2 - Структура системи самонавчання

Позначимо через $\mathrm{X}=\left(\mathrm{x}_{1}, \mathrm{x}_{2}, \ldots, \mathrm{x}_{\mathrm{n}}\right)$ - вектор інформативних ознак об'єкту класифікації, а через $\mathrm{t}_{1}, \mathrm{t}_{2}, \ldots, \mathrm{t}_{\mathrm{C}}-$ класи рішень. В нашому випадку нечіткий класифікатор це відображення $\mathrm{X} \rightarrow \mathrm{y} \in\left\{\mathrm{t}_{1}, \mathrm{t}_{2}, \ldots, \mathrm{t}_{\mathrm{C}}\right\}$, що реалізується за допомогою нечіткої бази знань. Нечітку базу знань цього відображення запишемо так [10]:

Якщо $\left(\mathrm{x}_{1}=ð_{1 \mathrm{j}}\right.$ та $\mathrm{x}_{2}=\mathrm{\partial}_{2 \mathrm{j}}$ та $\ldots \mathrm{x}_{\mathrm{n}}=\mathrm{\circlearrowright}_{\mathrm{nj}} 3$ вагою $\left.\mathrm{w}_{\mathrm{j}}\right)$, тоді:

$$
y=d j, j=\overline{1, m},
$$

де $\mathrm{m}$ - кількість правил; $\mathrm{d}_{\mathrm{j}} \in\left\{\mathrm{t}_{1}, \mathrm{t}_{2}, \ldots, \mathrm{t}_{\mathrm{C}}\right\}$ - значення консеквента $\mathrm{j}$-го правила; $\mathrm{w}_{\mathrm{j}} \in[0,1]$ ваговий коефіцієнт, що задає достовірність $\mathrm{j}$-го правила, $\mathrm{j}=\overline{1, \mathrm{~m}}$; $\mathrm{d}_{\mathrm{ij}}$ - нечіткий терм, що оцінює ознаку $\mathrm{x}_{\mathrm{i}}$ в $\mathrm{j}$-ому правилі $\mathrm{i}=1, \mathrm{n}, \mathrm{j}=\overline{1, \mathrm{~m}}$.

\section{Розробка математичної моделі динамічної бази знань}

В загальному випадку продукційну модель можна представити в наступному вигляді [25]:

$$
\mathrm{N}=<\mathrm{A}, \mathrm{U}, \mathrm{C}, \mathrm{I}, \mathrm{R}>\text {, }
$$

де N - ім'я ознаки; A - сфера застосування ознаки; U - умова використання ознаки; C ядро ознаки; I - постумови продукції, що актуалізуються при позитивній реалізації ознаки; R - коментарій, неформальне обгрунтування ознаки, час введення в базу знань, тощо.

Для проектування бази знань для керування судном нам потрібно визначити параметри U, C, I. Параметр А буде однаковий для всіх ознак, що належать до бази, що проектується, а параметр $\mathrm{R}$ не приймає безпосередньої участі в роботі системи та $\epsilon$ допоміжним.

Ядро ознаки можна представити у наступній формі:

$$
\mathrm{C}=\left(z_{j 1} \& z_{j 2} \& \ldots \& z_{j i} \Rightarrow d_{j 1} \& d_{j 2} \& \ldots \& d_{j i}\right)
$$

де $\mathrm{z}_{\mathrm{j} 1} \ldots \mathrm{z}_{\mathrm{ji}}-$ значення умов; $\mathrm{d}_{\mathrm{j} 1} \ldots \mathrm{d}_{\mathrm{ji}}-$ значення дій.

Для кожного порядкового номера умов множина значень визначена при проектуванні бази, тобто $\mathrm{z}_{\mathrm{ji}} \in \mathrm{Z}_{\mathrm{i}}$.

Режим використання знань полягає в наступному. Інтелектуальна система отримує дані про поточну поїзну обстановку у вигляді $\left(z_{j 1} \& z_{j 2} \& \ldots \& z_{j i}\right)$. Далі 
виконується порівняння отриманих даних з ознаками, що отримані раніше. Знаходяться ознаки, в яких умови співпадають з поточними. СППР згідно визначених правил обирає, яку ознаку слід використати в поточний момент часу.

Загалом робота бази знань описується таким алгоритмом. При роботі бази в режимі «Накопичення» відбувається поповнення і уточнення ознак. Якщо в базі знань знайдено ознаку, що тотожна поточним умовам керування судном, то іiі вага серед інших ознак підвищується шляхом підвищення параметра I. Якщо поточні умови керування судном та керуючі дії суднобригади не співпадають ні з однією існуючих ознак, то в базу додається нова ознака 3 поточними значеннями $\left(z_{j 1} \& z_{j 2} \& \ldots \& z_{j i}\right)$ та $\left(d_{j 1} \& d_{j 2} \& \ldots \& d_{j i}\right)$.

При роботі бази в режимі «Використання» СППР постійно контролює поточну поїзну обстановку та порівнює іiі з існуючими ознаками. У випадку співпадання СППР надає рекомендації по керуванню на підставі досвіду бази знань. Якщо поточна обстановка не відповідає жодній існуючій ознаці, то СППР не має можливості рекомендувати якісь керуючі дії i множина рекомендованих керуючих дій обнулюється.

Елементом, котрий реалізує функції управління системою являється інформаційно-управляючий пристрій, у склад якого входить людина-оператор. Система управління, людина-оператор й інформаційна підсистема працюють в умовах жорсткого дефіциту часу, і по конфігурації представляє собою комплекс із динамічною базою знань, яка розроблена вище і інтегрованою системою їх представлення.

Система управління маневруванням має наступні ієрархічні рівні: розробка заданого алгоритму функціонування; вимірювання параметрів поточного стану елементів; аналіз ситуації й ухвалення рішення по коригуванню алгоритму; формування команди на приведення системи в заданий стан; адаптація; виконання команди.

Для управління маневруванням була розроблена система основним чинником, який визначає точки, через які повинно пройти судно, є жорсткі обмеження. На їх положення не впливають мінливі обмеження i зовнішні дії. Незбурений стан змінюється при появі мінливих обмежень, коли необхідно коригувати траєкторію, яка повинна враховувати як мінливі, так і жорсткі обмеження. Оскільки система відкрита, то зовнішні дії змінюють фактичну траєкторію руху. Для проводки судна по плановій траєкторії необхідно коригувати тільки алгоритм і спосіб управління, зберігаючи прогнозовану безпечну.

Система отримання вирішального правила на основі аналізу альтернатив представляє наступну послідовність функціональних дій:

- формування вирішального правила для вибору рішення за умовами завдання. Формування вирішального правила проводиться в автоматизованому режимі або 3 залученням групи експертів, які формують вирішальну функцію в залежності від задачі, яка вирішується і сформованої системою критеріїв;

- вибір найбільш ефективного вирішення на основі сформованої вирішальної функції. Аналіз і вибір альтернатив здійснюється на основі сформованого вирішального правила. У разі відсутності рішення в підсистемі повинна передбачена можливість проведення експертної оцінки варіантів рішень на основі думок експертів з проблемноорієнтованої галузі [11].

Формування вирішального правила здійснюється спільно з експертною системою на основі сформованої бази знань правил, прийомів і методів прийняття рішень в залежності від різних ситуацій.

Автоматизоване формування вирішального правила відповідно до початкової системи критеріїв відбувається на основі людино-машинної взаємодії з системним аналітиком, яке формує цільову функцію на основі запропонованих методів (Рис.3). 


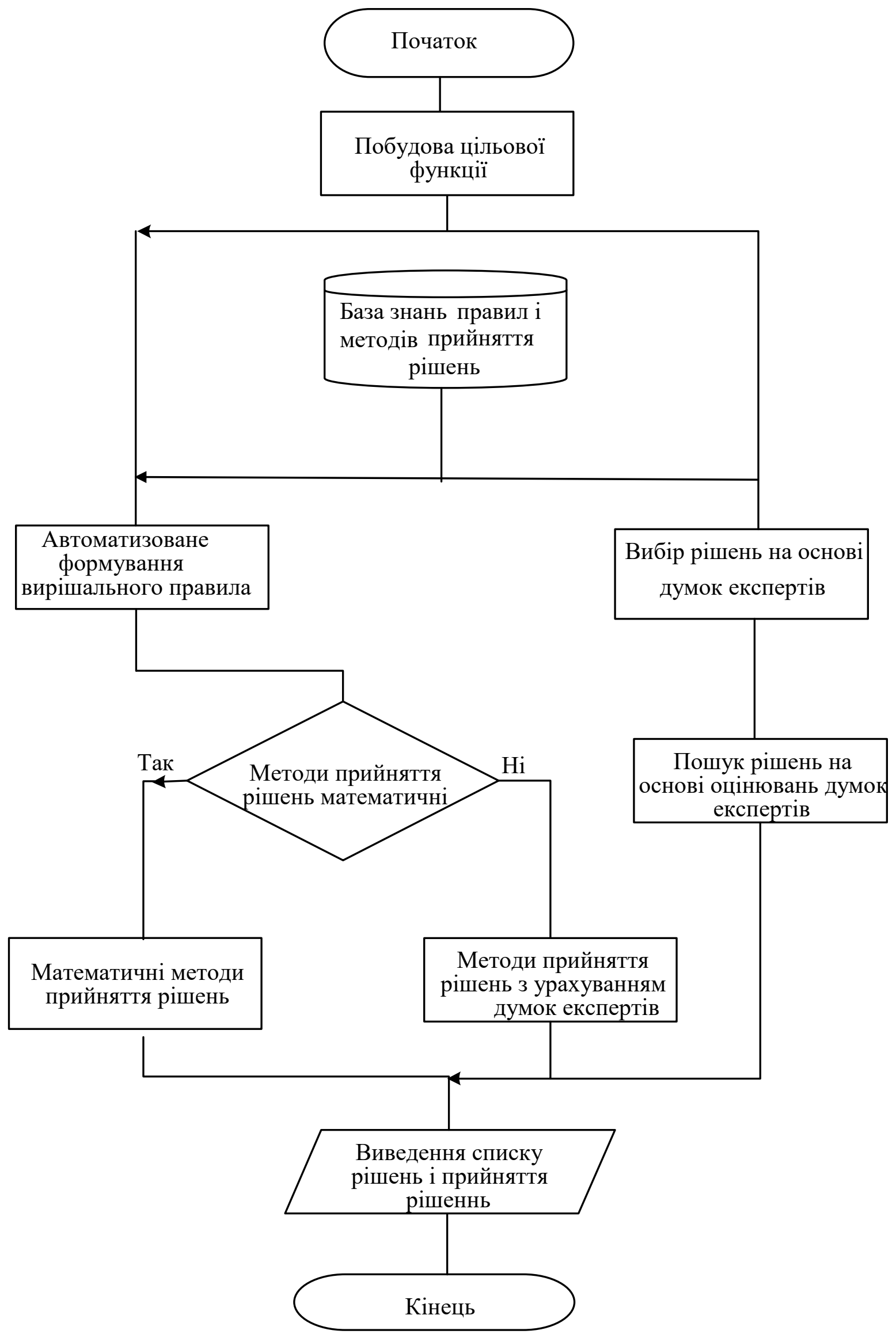

Рисунок 3 - Блок-схема алгоритму функціонування системи безпечного маневрування суден 
Сформовані раніше альтернативні варіанти аналізуються і якщо рішення задовольняють, то система припиняє роботу [12].

Експертне формування цільової функції визначається при взаємодії експертів на основі їх думок з експертною системою. Рішення відбирається на основі вибору експертами найкращого рішення з урахуванням їх вагомості [13].

Система дозволяє провести побудову вирішальної функції паралельно як в автоматизованому режимі, так і на основі експертної думки. Незалежне застосування правил дозволяє провести зіставлення вихідних рішень, отриманих в результаті їх функціонування системи.

Блок-схему алгоритму функціонування системи наведено на рис. 3.

Усі процедури підготовки до роботи виконуються 3 використанням природного інтелекту, і лише в електронних картах використовуються кібернетичні пристрої. Узагальненою причиною аварій є відсутність алгоритмів діяльності судноводія при плаванні в обмежених умовах, а також відмова від лоцманської проводки як елементу навігаційної безпеки. Дослідження підтвердили коректність метода оцінки узгодженості чинників руху i характеристик оператора, i дозволили провести ранжирування помилок оператора по його психофізіологічним характеристикам. Це означає, що рівень навику гармонізує 3 характеристиками оператора, i визначає успішність інтелектуальних дій по управлінню рухом при маневруванні.

Висновки. Розроблено структуру СППР судна, що відрізняється наявністю підсистеми оцінки складності поточної ситуації на воді. Це дозволило враховувати показник безпеки руху при прийнятті керуючих рішень. Самонавчання інтелектуальної системи реалізовано за допомогою нечіткого класифікатора. Розроблено модель бази знань, що має можливість доповнюватися в процесі використання та вести статистику рішень, що були реалізовані під час керування судном. На основі чого було розроблена блок-схема алгоритму функціонування системи безпечного маневрування суден, що дозволяє провести побудову вирішальної функції паралельно як в автоматизованому режимі, так і на основі експертної думки. Незалежне застосування правил дозволяє провести зіставлення вихідних рішень, отриманих в результаті їх функціонування системи.

\section{ЛIТЕРАТУРА}

1. Васильев С. Н. (2000). Интеллектуальное управление динамическими системами / С. Н. Васильев [и др.]. - М.: Физматлит, 352 с.

2. Цымбал Н.Н., Бужбецкий Р.Ю. (2006). Формализация МППСС-72 в части координации взаимодействия судов при расхождении . Судовождение. № 12. С. 124-129.

3. Дмитриев С.П. (2001). Автоматический синтез траекторий движения как средство интеллектуальной поддержки судоводителя / С. П. Дмитриев и [др.] // Гироскопия и навигация. № 3 (34). С. 19-31.

4. Дмитриев С.П., Колесов Н.В., Осипов А.В., Романычева Г.Н. Система интеллектуальной поддержки судоводителя при расхождении судов. Известия Российской академии наук. Теория и системы управления. №2. С. 98-105.

5. Глушков, С.В. Методы повышения качества управления судном на основе использования нейросетевых технологий: дис. докт. техн. наук / С.В. Глушков - Мор. гос. ун-т им. адмирала Г.И. Невельского. Владивосток. 2008. $-175 \mathrm{c}$

6. Пипченко А.Д. (2003). Разработка робастного регулятора курса судна на базе теории искусственных нейронных сетей. Судовождение: Сб. научн. трудов ОНМА. - Одесса: ИздатИнформ. № 1. С. 15-21.

7. Gelb, A. (1974). Applied optimal estimation. MIT Press, $374 \mathrm{p}$ 
8. Горобченко, О. М. (2011). Корегування функцій машиніста локомотива за допомогою систем підтримки прийняття рішень. - информ. № 5. С. 4-5.

9. Штовба С.Д. (2007). Проектирование нечетких систем средствами MATLAB [Текст]. - Москва: Горячая линия. -288 с.

10. Ириков В.А., Тренев В.Н. (1999). Распределённые системы принятия решений. Теория и приложения: Наука. Физматлит, 288 с.

11. Рейльян Я. Р. (1989). Аналитическая основа принятия управленческих решений. Финансы и статистика, 208 с.

12. Рыков А.С. (2000). Методы системного анализа: многокритериальная и нечёткая оптимизация, моделирование и экспертные оценки. Экономика, 316 с.

\section{REFERENCES}

1. Vasiliev S.N. (2000). Intelligent control of dynamic systems / SN Vasiliev [et al.]. Moscow: Fizmatlit, 352 p.

2. Tsymbal N.N., Buzhbetsky R.Yu. (2006). Formalization of COLREGs-72 in terms of coordination of interaction of ships in case of divergence. Navigation. No. 12. pp. 124 129.

3. Dmitriev S.P. (2001). Automatic synthesis of motion trajectories as a means of intellectual support for the navigator / S. P. Dmitriev et al. // Gyroscopy and navigation. No. 3 (34). S. 19-31.

4. Dmitriev S.P., Kolesov N.V., Osipov A.V., Romanycheva G.N. The system of intellectual support for the navigator in case of diverging vessels. Bulletin of the Russian Academy of Sciences. Theory and control systems. \# 2. S. 98-105.

5. Glushkov, S.V. Methods for improving the quality of ship management based on use of neural network technologies: dis. doct. tech. Sciences / S.V. Glushkov - Mor. state un-t them. Admiral G.I. Nevelsky. Vladivostok. - 2008 .-- $175 \mathrm{~s}$

6. Pipchenko A.D. (2003). Development of a robust ship course controller based on the theory of artificial neural networks. Navigation: Sat. scientific. works of ONMA. Odessa: IzdatInform. No. 1. P. 15-21.

7. Gelb, A. (1974). Applied optimal estimation. MIT Press, $374 \mathrm{p}$

8. Gorobchenko, O. M. (2011). Correlation of the functions of the locomotive engine for the additional support of the driver's systems is accepted. - inform. No. 5. P. 4-5.

9. Shtovba S.D. (2007). Designing fuzzy systems using MATLAB [Text]. - Moscow: Hotline. - $288 \mathrm{p}$.

10. Irikov V.A., Trenev V.N. (1999). Distributed decision-making systems. Theory and Applications: Science. Fizmatlit, 288 p.

11. Reilyan Ya.R. (1989). An analytical basis for making management decisions. Finance and statistics, $208 \mathrm{p}$.

12. Rykov A.S. (2000). Systems analysis methods: multi-criteria and fuzzy optimization, modeling and expert assessments. Economics, $316 \mathrm{p}$.

Скляренко И.Ю., Смирнова И. М., Герчиков А. А., Сидорчук А.Р

РАЗРАБОТКА И ВНЕДРЕНИЕ АЛГОРИТМА БЕЗОПАСНОГО МАНЕВРИРОВАНИЯ СУДОВ ВНУТРЕННЕГО ПЛАВАНИЯ

В статье рассмотрены проблемы обеспечения безопасного маневрирования судов, приведены факторы влияния на маневрирования судами внутреннего плавания, дано определение системе автоматического управления судном, что является основой процесса перехода к безэкипажным суднам. Рассмотрены виды современных адаптивных авторулевых систем управления судами, исследованы их основные особенности, что стало основой для разработки системы поддержки принятия решений судами. Доказано, что для разработки логических структурных алгоритмов принятия 
решения уделяется внимание разработке методов корректировки плановой траектории при управлении расхождением судов. При большом их количестве задача значительно усложняется, и судоводитель вынужден решать только оперативные задачи. Оченку ситуачии изменение относительного движения описано тремя характеристиками. Представленны модель задачи принятия решения, схема системь самообучения, математическая модель динамической базы знаний на основе чего было построено алгоритм функционирования системь безопасного маневрирования, что позволяет провести построение решающей функции параллельно как в автоматизированном режиме, так и на основе экспертного мнения.

Ключові слова: система управління, маневрування, система підтримки прийняття рімень, база даних, алгоритм.

\section{Sklyarenko I.Y., Smirnova I.M., Gerchikov O.O., Sidorchuk O.R. DEVELOPMENT AND IMPLEMENTATION OF AN ALGORITHM FOR SAFE MANEUVERING OF INLAND NAVIGATION VESSELS}

The article considers the problems of ensuring safe maneuvering of vessels, presents the factors influencing the maneuvering of inland waterway vessels, defines the system of automatic control of the vessel, which is the basis of the process of transition to unmanned vessels. The types of modern adaptive autopilot systems of ship management are considered, their main features are investigated, which became the basis for the development of a decision support system for ships.

It is investigated that for development of logical structural algorithms of decisionmaking attention is paid to development of methods of adjustment of a planned trajectory at management of a difference of vessels. With a large number of them, the tasks become much more complicated, and the driver is forced to solve only operational tasks. Assessment of the situation change in relative motion is described by three characteristics. The model of the problem of decision-making, the scheme of the self-learning system, the mathematical model of the dynamic knowledge base on the basis of which the algorithm of functioning of the safe maneuvering system was constructed is presented.

Keywords: control system, maneuvering, decision support system, database, algorithm. 